\title{
CONFIRMATION OF UTRICULARIA AUSTRALIS OCCURRENCE IN LITHUANIA
}

\section{Zofija SinKeVIČIENĖ}

Nature Research Centre, Institute of Botany, Žaliujų Ežerų Str. 49, LT-08406 Vilnius, Lithuania E-mail: zofija.sinkeviciene@botanika.lt

\begin{abstract}
Sinkevičienė Z., 2013: Confirmation of Utricularia australis occurrence in Lithuania [Utricularia australis auga ir Lietuvoje]. - Bot. Lith., 19(2): 161-164.

Occurrence of Utricularia australis R. Br. on the territory of Lithuania was confirmed by finding it in Lake Kampinis, Varèna district municipality. Morphological differences between similar species U. australis and Utricularia vulgaris as well as species composition of the association Utricularietum australis and accompanying communities are presented and discussed.
\end{abstract}

Keywords: carnivorous plants, aquatic macrophytes, Utricularia australis, Utricularietum australis, Lithuania.

Utricularia australis $\mathrm{R}$. Br. is a carnivorous aquatic plant species widely distributed in temperate and tropical regions, except North and South America (TAYLOR, 1989). It grows in natural still and slowly flowing water and also in ditches of rice fields. $U$. australis is treated as native in all European countries, where it grows (UотіLA, 2013). Almost completely sterile $U$. australis f. australis is originated from the hybridization between fertile $U$. australis f. tenuicaulis, which is recorded only in Japan, and Utricularia macrorhiza (KAMEYAMA et al., 2005). Successful vegetative propagation ensured widespread of the vigorous hybrid.

Occurrence of Utricularia australis $(=U$. neglegta Lehm.) in Lithuania has been presumed by many authors (KuPREviČIUS, 1934; SNARSKIS, 1954; JANKEVIČIENÉ, 1976; GUDŽINSKAS, 1999), basing on the records in neighbouring countries. This species is reported as rare in Estonia and Latvia (MÄEMETS et al., 1996). The need of further investigations on its distribution is indicated, as plants in vegetative condition are very similar to Utricularia vulgaris.

Large population of Utricularia australis was discovered on 3 August 2010 in a small (area of
$0.03 \mathrm{~km}^{2}$ ) glacial Lake Kampinis (south of Lithuania, Varèna district, $54^{\circ} 12^{\prime} 12.57^{\prime}$ N, 24 $4^{\circ} 11^{\prime} 17.7^{\prime}$ ' E) (Fig. 1). The temperature and $\mathrm{pH}$ of water was measured in situ using portable meter Multiline F/Set-3. Transparency of water was measured with Secchi disk. Distribution of plants in the lake was estimated and communities with $U$. australis were studied after Braun-Blanquet (1964). Phytosociological nomenclature follows ŠumBEROVÁ (2011).

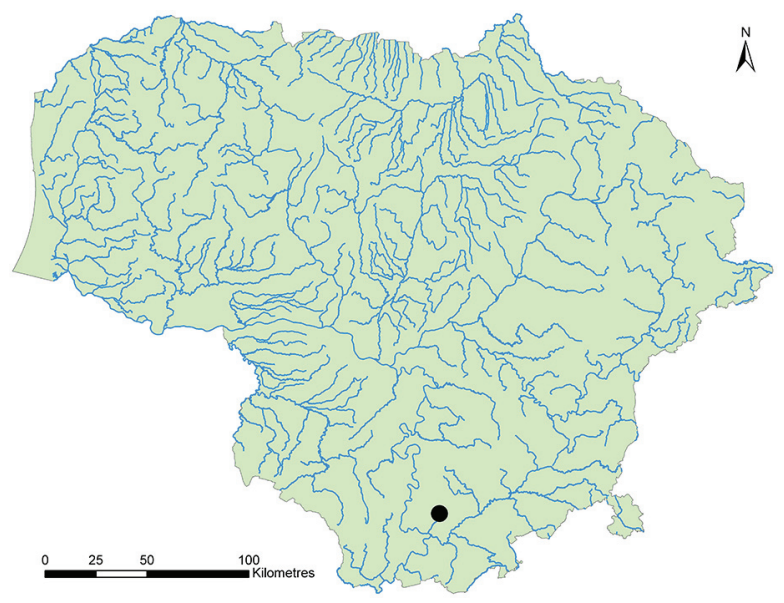

Fig. 1. Locality of Utricularia australis in Lithuania 
According to the transparent water (Secchi depth $3.6 \mathrm{~m}$ ) and sandy bottom, the lake seems to be poor in nutrients. High temperature on the surface of water $\left(28^{\circ} \mathrm{C}\right)$ and neutral reaction $(\mathrm{pH} 7.26)$ probably were favourable for luxuriant development and flowering of the southern species. Flowering plants of Utricularia australis were easily recognized by the almost flat lower lip of the corolla with spread slightly undulate margins (Table 1, Fig. 2). This obvious feature, clearly separating $U$. australis from Utricularia vulgaris in the field, was completely undetectable in the dried material. $U$. australis was distributed mainly along the eastern shore of the lake at a depth from 0.5 to $3 \mathrm{~m}$. It grew scarce in the belt of Phragmites australis and was abundant in communities of floating-leaved plants or formed mono-dominant patches (Table 2). Flowering U. australis plants floating on the water surface dominated in the area at a depth of 1.0-2.0 metres, whereas vegetative plants formed submerged patches or co-occurred with other submerged plants in the deepest locations of 3.0 metres.

Locality and date of relevés: Varèna district municipality, Lake Kampinis. 3 August 2010.

Four phytosociological relevès with dominant Utricularia australis were attributed to association Utricularietum australis (Table 2). This association is assigned to the class Potamogetonetea by MATUSZKIEWICZ (2005) or to Lemnetea by Šumberová (2011). In Lake Kampinis, these communities formed a complex with phytocenoses of the class Potamoge-

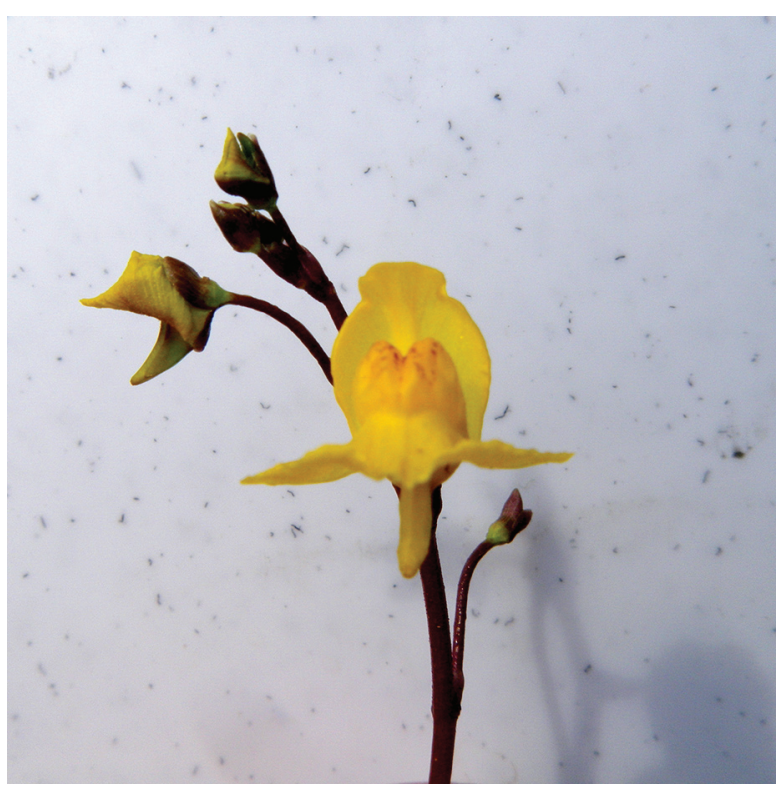

Fig. 2. Characteristic view of Utricularia australis flower with flat lower lip of the corolla, spread margin and upper lip distinctly longer as palate

tonetea. Pleustonic Lemnaceae species or communities were not found.

Sixty-eight herbarium specimens of Utricularia vulgaris collection in the Herbarium BILAS were revised. Special attention was paid to the specimens collected after the revision of the Flora of the Baltic Countries (MÄEMETS et al., 1996). More than half of all revised specimens were collections of vegetative plants, because many populations especially in deep waters persist and

Table 1. Morphological distinctions between Utricularia australis and U. vulgaris (after TAYLOR, 1972; ZAO SCHU, 2011; TAHIR, 2011)

\begin{tabular}{|c|c|}
\hline Utricularia australis & Utricularia vulgaris \\
\hline \multicolumn{2}{|c|}{ Generative features } \\
\hline Corolla deep yellow & Corolla lemon-yellow \\
\hline Upper lip longer as palate & Upper lip \pm as long as the gibbous palate \\
\hline Lower lip of corolla \pm flat with spread undulate margin & Lower lip of corolla with deflexed margin \\
\hline Palate of corolla glabrous & Palate of corolla pubescent \\
\hline $\begin{array}{l}\text { Glands inside the apex of the corolla spur with glands on } \\
\text { both dorsal and ventral surfaces }\end{array}$ & $\begin{array}{l}\text { Glands inside the apex of the corolla spur on dorsal surface } \\
\text { only }\end{array}$ \\
\hline Anther thecae distinct & Anther thecae confluent \\
\hline Bracts orbicular & Bracts ovate \\
\hline $\begin{array}{l}\text { Pedicels 3-5 times as long as the bract, erect or patent in } \\
\text { fruit }\end{array}$ & $\begin{array}{l}\text { Pedicels } 2-3 \text { times as long as the bract, strongly recurved in } \\
\text { fruit }\end{array}$ \\
\hline Plants sterile & Plants fertile, capsule globose \\
\hline \multicolumn{2}{|c|}{ Vegetative features } \\
\hline Leaves with 2 primary segments & Leaves with $2-4$ primary segments \\
\hline $\begin{array}{l}\text { Capillary leaf segments with setulae arising from the apex of } \\
\text { the short teeth }\end{array}$ & $\begin{array}{l}\text { Capillary leaf segments with setulae directly arising from the } \\
\text { margins, without any teeth }\end{array}$ \\
\hline
\end{tabular}


Table 2. Species composition of the communities with Utricularia australis

\begin{tabular}{|c|c|c|c|c|c|c|c|c|c|c|}
\hline Number of relevès & 1 & 2 & 3 & 4 & 5 & 6 & 7 & 8 & 9 & 10 \\
\hline Cover, $\%$ & 100 & 100 & 100 & 60 & 90 & 90 & 90 & 70 & 80 & 100 \\
\hline Depth, m & $1.0-2.0$ & $1.0-2.0$ & $1.0-2.0$ & 3.0 & $1.2-3.0$ & $1.0-1.1$ & $0.2-1.0$ & $1.0-2.0$ & 2.5 & $2.0-3.0$ \\
\hline Number of species in relevè & 4 & 5 & 5 & 3 & 3 & 6 & 7 & 7 & 4 & 2 \\
\hline \multicolumn{11}{|l|}{ Ch. Ass. } \\
\hline Utricularia australis A. Br. & 5 & 5 & 5 & 3 & 2 & 2 & 1 & 1 & 2 & + \\
\hline Potamogeton natans L. & 1 & 1 & & & 4 & 4 & 3 & 1 & & \\
\hline Nuphar luteum (L.) Sm. & 1 & 1 & 1 & & 1 & 1 & & 3 & + & \\
\hline Myriophyllum spicatum L. & & + & & & & & & & 4 & \\
\hline Ceratophyllum demersum $\mathrm{L}$. & & & & & & & & 1 & & 5 \\
\hline \multicolumn{11}{|l|}{ Cl. Potametea } \\
\hline $\begin{array}{l}\text { Persicaria amphibia (L.) } \\
\text { Gray }\end{array}$ & & & & & & & 2 & & & \\
\hline $\begin{array}{l}\text { Batrachium circinatum } \\
\text { (Sibth.) Spach }\end{array}$ & & & & & & & & & 1 & \\
\hline Myriophyllum verticillatum L. & + & & + & & & & & & & \\
\hline Potamogeton lucens L. & & & + & & & & & & & \\
\hline \multicolumn{11}{|l|}{ Accompanying species } \\
\hline $\begin{array}{l}\text { Phragmites australis (Cav.) } \\
\text { Trin ex Steud. }\end{array}$ & & + & + & & & & 1 & & & \\
\hline Equisetum fluviatile L. & & & & & & 1 & 1 & + & & \\
\hline Carex rostrata Stokes & & & & & & + & 1 & & & \\
\hline $\begin{array}{l}\text { Schoenoplectus lacustris (L.) } \\
\text { Palla }\end{array}$ & & & & & & & + & 1 & & \\
\hline Typha latifolia $\mathrm{L}$. & & & & & & + & & + & & \\
\hline Chara globularis Thuill. & & & & 1 & & & & & & \\
\hline $\begin{array}{l}\text { Eleocharis acicularis (L.) } \\
\text { Roem et Schult. }\end{array}$ & & & & 1 & & & & & & \\
\hline
\end{tabular}

Syntaxonomical units (after ŠumberovÁ, 2011): relevès 1-4 - Utricularietum australis Th. Müller et Görs 1960; relevès 5-7 - Potametum natantis Hild 1959; relevè 8 - Nymphaeo albae-Nupharetum luteae Nowiński 1927; relevè 9 - Potamo pectinati-Myriophylletum spicati Rivas Goday 1964; relevè 10 - Ceratophylletum demersi Corillion 1957.

spread only vegetatively. As mentioned above, vegetative distinctions between $U$. australis and $U$. vulgaris are negligible and should be supported by generative features (Table 1). The revision of 32 flowering plant specimens revealed that such features as distribution of the glands inside the apex of the corolla spur, presence or absence of hairs on the palate of corolla and ratio between the length of upper lip and palate can be observed only in a part of the dried specimens. Plant fertility, the length of pedicels and its curvature is possible to check in both fresh and dry specimens.

Features, characteristic to Utricularia australis, as dorsal and ventral spur glandulation and distinct stamen anthers were observed in two herbarium specimens. V. Stepanavičienè collected both speci- mens in small water bodies within limits of Vilnius City at the early stage of flowering. The occurrence of $U$. australis in these locations can be adjusted during the nearest vegetation season.

In conclusion it can be predicted that $U$. australis is more widely distributed in the country, at least in the southern Lithuania. On the other hand, revision of the herbarium specimens confirmed that this species is much rarer than $U$. vulgaris.

\section{ACKNOWLEDGEMENTS}

I am grateful to Jūrate Karosienè for the assistance during the field work. 


\section{REFERENCES}

Braun-Blanquet J., 1964: Pflanzensoziologie: Grundzüge der Vegetationskunde. - Wien.

GuDŽINSKAS Z., 1999: Lietuvos induočiai augalai.Vilnius.

Kameyama Y., Toyama M., Ohara M., 2005: Hybrid origins and $\mathrm{F} 1$ dominance in the free-floating, sterile bladderwort, Utricularia australis $\mathrm{f}$. australis (Lentibulariaceae). - American Journal of Botany, 92(3): 469-476.

JANKEVIČIENĖ R., 1976: Skendeniniai - Lentibulariaceae Lindl. - In: NATKeVIČAItĖ-IVANAuSKIENĖ M. (ed.), Lietuvos TSR flora, 5: 497-503. - Vilnius.

Kuprevičıus J. (ed.), 1934: Vadovas Lietuvos augalams pažinti. - Kaunas.

Mäemets A., Eglite Z., SinkevičIenė Z., 1996: Lentibulariaceae L.C.Rich. - In: KuUsK V., TABAKA L., JANKEVIČIENE R. (eds), Flora of the Baltic Countries, 2: 344-346. - Tartu.

Matuszkiewicz W., 2005: Przewodnic do oznaczania zbiorowisk roślinnych Polski. - Warszawa.

SNARSKIS P., 1954: Vadovas LTSR augalams pažinti. Vilnius.
Šumberová K., 2011: VA Lemnetea de Bolós et Masclans 1955. - In: CHYtRÝ M. (ed.), Vegetace České republiky. 3. Vodni a mokradni vegetace: 43-46. - Praha. -http://www.sci.muni.cz/botany/ vegsci/vegetace.php?lang=en\&typ=VA/ (accessed 25-11-2013).

TAHIR A., 2011: Utricularia L. - In: Flora of Pakistan. -http://www.efloras.org/florataxon.aspx?flora $\mathrm{id}=5 \&$ taxon_id=134270/ $($ accessed $28-11-2013)$.

TAYlor P., 1972: Utricularia L. - In: Tutin T.G. (ed.), Flora Europaea, 3: 296-297. - Cambridge.

TAYLOR P., 1989. The genus Utricularia - a taxonomic monograph. - Kew bulletin. Additional series, 14: 1-724.

Uotila P., 2013: Lentibulariaceae. - In: Euro+Med Plantbase - the information resource for Euro-Mediterranean plant diversity. - http://ww2.bgbm.org/ EuroPlusMed/PTaxonDetail.asp?NameCache $=\mathrm{L}$ entibulariaceae\&PTRefFk $=7500000 /$ (accessed 25-11-2013).

Zao Schu L., 2011: Utricularia L. - In: Zhengovi W., Raven P.H., Devuan H. (eds), Flora of China, 19: 481-491. - Cambridge.

\section{UTRICULARIA AUSTRALIS TIKRAI AUGA IR LIETUVOJE}

\section{Zofija SINKEVIČIENĖ}

\section{Santrauka}

Pelkinis skendenis (Utricularia australis) pirma kartą Lietuvoje aptiktas $2010 \mathrm{~m}$. rugpjūčio $3 \mathrm{~d}$. Kampinio ežere (Varènos r. sav., koordinatès 54 $12^{\prime}$ $12.57^{\prime}$ ' N, 24 $11^{\prime} 17.7^{\prime}$ ' E). Labai vešlūs žydintys augalai sudarè iki $10 \mathrm{~m}$ pločio juostą rytiniame ežero pakraštyje. Nuo labai panašaus paprastojo skendenio (Utricularia vulgaris) žydintis pelkinis skendenis lengvai skiriasi išskleistais plokščios apatinès žiedo lūpos pakraščiais, tačiau šis požymis visiškai prarandamas išdžiovintuose herbariumo pavyzdžiuose. Kiti skiriamieji pelkinio skendenio morfologiniai žiedų požymiai: viršutinè lūpa žymiai ilgesnè už pliką apatinès lūpos gūbrị; liaukutès pentino viduje išsidėsčiusios ir dorsalinèje ir ventralinèje dalyse; žiedkočiai 3-5 kartus ilgesni už pažiedes, po žydejjimo išlieka statūs arba šiek tiek palinkę, bet niekada nenulinksta žemyn; vaisių dėžutès nesusiformuoja, nes augalai sterilūs. Kampinio ežere pelkinis skendenis sudaro Utricularietum australis bendrijas arba izeina i plūdurlapių (Potametum natantis, Nymphaeo albaeNupharetum luteae) ir pasinèrusių augalų (Potamo pectinati-Myriophylletum spicati, Ceratophylletum demersi) bendriju sudèti. Šis radinys patvirtina, kad pelkinis skendenis tikrai auga Lietuvoje, tačiau pagal herbariumo rinkinių peržiūros duomenis ši rūšis žymiai retesnè negu paprastasis skendenis. 